\title{
Impacts of Human Capital Development on Real Sectors Growth in Nigeria
}

\author{
Obasanmi Jude Omokugbo, Idogun Henry Imogiemhe
}

Department of Economics, Ambrose Alli University, Ekpoma, Nigeria

Email address:

obasanmijude@gmail.com (O. J. Omokugbo)

\section{To cite this article:}

Obasanmi Jude Omokugbo, Idogun Henry Imogiemhe. Impacts of Human Capital Development on Real Sectors Growth in Nigeria. Journal of Finance and Accounting. Special Issue: Financial Inclusion, Accounting Perspectives and Development. Vol. 8, No. 1, 2020, pp. $24-33$. doi: $10.11648 /$ j.jfa.20200801.14

Received: December 3, 2019; Accepted: January 10, 2020; Published: February 14, 2020

\begin{abstract}
Human capital is an important factor used in converting all resources to mankind's use and benefit. In an attempt to examine the nexus between human capital development and real sector growth indicators (Agriculture and Petroleum and Natural Gas), this study investigated the relationship between human capital development and real sector growth in Nigeria. Annual time series data from 1990 to 2018 was employed. The Augmented Dickey Fuller (ADF), Johansen-Cointegration, and Error Correction Mechanism (ECM) were employed in the study. The result indicated long run relationship between human capital development and output growth in the two sectors investigated. The result revealed that current public expenditure on education and health translated in increase in output for Petroleum \& Natural Gas in Nigeria but not in the Agricultural sector. Also, expenditure in research and development (R\&D) had significant impact on output growth in the two sectors. It was recommended that the federal government should endeavor to increase their expenditure on education to boost quality education infrastructure needed in schools.
\end{abstract}

Keywords: Human Capital, Real Sectors, Agriculture, Petroleum, Education and Natural Gas

\section{Introduction}

\subsection{Background to the Study}

The issue of human capital development has continued to gain recognition in public policy plan of many developing countries including Nigeria. This has been attributed to Nigeria's aspiration to be globally recognized among the 20 leading economies in the world by the year 2020. Generally, the rationale behind human capital development hinges on promoting an amalgam of factors such as education, health, work experience, intelligence, energy, work habits, trustworthiness and initiative of worker through quality training to affect the value of a worker's marginal product [1].

In measuring human capital, the United Nations Development Programme [2] identified that there are nine global indicators of human capital development in any given nation. Some of these indicators include: national income and composition of resources indicators; work and employment indicators; population trend indicators; human security indicators such as number of internally displaced and homeless people; international integration indicators, such as net official development assistance, remittance inflows, stock of immigrant, number of internet users and mobile phone subscription; and status of fundamental human right treaties. This therefore suggests that the quality of a nation's real sector output and aggregate income is expected to grow proportionately with the quality of the people in it. This rational expectation justifies the reason government and stakeholders in most developing nations in Sub-Sahara Africa advocate for free, compulsory and quality education for its citizens, particularly at the primary and basic levels.

The real sector describes the amalgam of agencies, institutions and industries driven by the private and/or the public sector; whose aggregate output in monetary terms, contribute to the nation's Gross Domestic Product (GDP). They include but are not restricted to firms operating in the Agricultural sector, Services Sector, Solid Mineral Sector, Manufacturing Sector, Construction and Trade, Petroleum and Natural Gas Sector. Over the years, these sectors have generated only marginal increases in GDP. In all these sectors, some studies have opined that if Nigeria is to benefit 
from the great potentials available in the real sector a lot of investment must be made in the development of human component involved in production. Adelakan [3] and Ogunniyi [4] suggested that the only way one may sustain growth in the solid mineral sector is to boost the capacities of the workforce operating in the real sector by investing in the development of human capital.

This study examines the relationship between human capital development in two real sectors (Agriculture and Petroleum) in Nigeria from 1990-2018. These sectors were adjudged independently as sectors with high demand for human capital. Education achievement, health outcomes, work-employment quality, national income composition and international integration indices were used as proxy for quality of human capital development programme in the country. Finding out whether or not human capital development promotes real sector growth is very important as it would enable policy makers, the Federal and State government to be sensitized in the right policy direction, to maximize the inherent potential of various sectors of the economy. Also, findings from this study would contribute to knowledge and add up to empirical literature that could be of immense benefit to prospective researchers who wish to carry out further studies on the subject in future.

\subsection{The Research Problem}

Inspite of the nation's huge oil wealth, the country has relatively remained one of the poorest among other nations in terms of human capital development. There has been poor performance in service delivery, bad road infrastructures, poor power, energy, transportation, politics and finance sector [5]. Despite having a smooth democratic practice that has lasted for over 20 years uninterrupted, the economy is still struggling to leverage on the country's vast wealth in fossil fuels in order to displace the devastating lack that affects about 57 percent of its population. This is against the background that crude oil has been the source of Nigeria's mainstay since independence.

Studies by Jelilov, Aleshinloye and Önder [1], Jaiyeoba [5] and Edun, Akinde and Olaleye [6] have tried to investigate the impact of human capital on national growth in Nigeria. These studies differently, restricted their analysis to economic growth. This could be misleading in that the growth of one or more sectors of the economy does not imply that all the sectors in the economy are contributing to aggregate demand or national growth. Consequently, the impact of human capital development on overall economic growth has often been investigated, while the effect of human capital development efforts on the output of prominent sectors such as those in the Agricultural Sector and Petroleum and Natural Gas sector has remained unclear from studies Ogunniyi [4] and Oloyede [7]. It is against this background that the study examined the link between human capital development and real sector growth from a disaggregated view with focus on some components of the real sector of the Nigerian Economy-Agricultural and Petroleum and Natural Gas sectors

\subsection{Objectives of the Study}

The main objective of this study is an assessment of the impacts of human capital development on selected real sectors growth in Sub-Sahara Africa: The Case of Nigeria. Specifically, the objectives of the study are to:

i. investigate the effect of human capital development on growth in the Agricultural Sector of Nigeria;

ii. determine the relationship between human capital development and growth in the Petroleum and Natural Gas Sector of Nigeria.

\subsection{Research Hypotheses}

$\mathrm{H}_{\mathrm{O} 1}$ : Human capital development has no significant impact on growth in the Agricultural Sector of Nigeria.

$\mathrm{H}_{\mathrm{O} 2}$ : Human capital development has no significant relationship with growth in the Petroleum and Natural Gas Sector of Nigeria.

\section{Literature Review}

\subsection{Conceptual Issues}

Human capital as an economic term encompasses health, education and other human capacities that can raise productivity [8]. Capital and natural resources are passive factors of production while human resources are active factors of production. Human capital constitutes the most valuable resource of a country; in its absence there will be the non-performance of physical capital (tools, machinery, and equipment) which will impede economic growth. Imahe [9] opined that, human capital refers to the abilities and skills of human resources in a given society or country, while human capital formation refers to the process of acquiring and increasing the number of people who have the skills, education and experience that are critical for economic growth and development of a country.

The key output sectors that make up the real sector are the primary sector (Agriculture \& Mining), the secondary sector (manufacturing and building \& construction) and the tertiary sector (services and commerce), collective production, distribution, sale and consumption of goods, services and accommodation. The real sector is a term that describes the amalgam of agencies, institutions and industries driven by the private and/or the public sector; whose aggregate output in monetary terms, contribute to the nation's GDP.

The Nigerian petroleum sector is another major sector in the real sector of the economy. The sector is vested in the Federal Government of Nigeria by virtue of the Constitution. The Nigerian National Petroleum Corporation (NNPC) Act empowers the NNPC to engage in all commercial activities relating to the petroleum sector and to enforce all regulatory measures [10]. The oil sector consists of the upstream ventures which encompass exploration, oil production, and crude oil marketing; midstream ventures which encompasses refining of crude oil, transportation and importation; and a downstream venture which encompasses retail services, distribution, 
research and development and investment opportunities.

The summary of all this is that human capital as a critical element affects economic growth and if properly harnessed can help to develop an economy by expanding the knowledge and skills of its people. Since skills provide economic value, it therefore infers that there is a direct relationship between a knowledgeable workforce and productivity [11].

\subsection{Theoretical Literature}

Contemporary discussions on human capital development and real sector growth have dominated several theories. The Endogenous growth or the new growth theory emerged in the 1990 s to explain the poor performance of many less developed countries, which have implemented policies as prescribed in neoclassical theories. Unlike the Solow model that considers technological change as an exogenous factor, the new growth model notes that technological change has neither been equal nor been exogenously transmitted in most developing countries [12].

New growth theorists linked the technological change to the production of knowledge. The new growth theory emphasizes that economic growth results from increasing returns to the use of knowledge rather than labour and capital. The theory argues that the higher rate of returns as expected in the Solow model is greatly eroded by lower levels of complementary investments in human capital (education), physical infrastructure, or research and development (R\&D). Knowledge or innovation can be reused at zero additional cost. Investments in knowledge creation therefore can bring about sustained growth. Moreover, the knowledge could create the spillover benefits to other firms once obtained [13-14].

Furthermore, Human Capital Theory shows how education leads to increase in productivity and efficiency of workers by increasing the level of their cognitive skills. Theodore, Schultz, Gory Bucker and Jacob Mincer introduced the notion that people invest in education so as to increase their stock of human capabilities which can be formed by combining innate abilities with investment in human beings [15]. As the global economy shifts towards more knowledge based sectors (e.g., the manufacture of ICT based services, R\&D) skills and human capital development becomes a central issue for policy makers and practitioners engaged in economic development, both at the national and regional levels [16]. Yet, the impact education and vocational training activities exert upon changing national and regional economies remains less than thoroughly explained and analyzed. Since the introduction of human capital theory in the 1960s, a number of studies have attempted to address this and other related issues [11].

The Modernization Theory focuses on how education transforms an individual's value, belief and behaviour. Exposure to modernization institutions such as schools, factories, and mass media inculcate modern values and attitudes. The attitude includes openness to new ideas, independences from traditional authorities, and willingness to plan among others. According to modernization theorists, these normative and attitudinal changes continue throughout the life cycle, permanently altering the individual's relationship with the social structure [17]. The greater the number of people exposed to modernization institutions, the greater the level of individual modernity attained by the society [18]. Once a critical segment of a population changes in this way; the pace of society's modernization and economic development quickens. Thus, educational expansion through its effects on individual values and benefits sets in motion the necessary building blocks for a more productive workforce and a more sustained economic growth [3].

The Theory of Coordination Failure: The foundation of the theory of coordination failure is the idea that the financial market may fail to achieve coordination among complementary activities. When complementaries exist, that is when returns of one investment depend on the presence or extent of other investments; there exist two scenarios. On the one hand, optimally, all investors as a whole are better off with all investments to be achieved at the same time. On the other hand, it would not make sense for an investor to take similar actions when he believes that others may not do the same as well. The market is said to have failed to coordinate investors' actions in this way. Coordination failure therefore leads the market to an equilibrium, inferior to a potential situation in which resources would be optimally allocated and all agents would be better off. As a result, underdevelopment equilibrium is possible [19]

As reported by Adelakun [3], the Dependency theory arose from Marxist conceptualizations based on the dynamic world system that structures conditions for economic transformation in both the core and periphery of the world economy. Certain features of the world polity such as state fiscal strength, degrees and regime centralization and external political integration may contribute to economic growth in the developing world.

\subsection{Empirical Literature}

An examination of human capital development and the economic growth in Nigeria was the focus of Adelakun [3] study. He described human capital as an important factor used in converting all resources to mankind's use and benefit. The study evaluates human capital development and economic growth in Nigeria by adopting conceptual analytical framework as well as employing Ordinary Least Square (OLS) to analyse relationship between human capital development and economic growth. The findings revealed that there is strong relationship between human capital development and economic growth. The policy implication recommends that proper institutional framework should be put in place to look into manpower needs of various sectors and implement policies that can lead to the overall growth of the economy.

Oloyede [7] examined the impact of human capital development on economic growth in Nigeria. The specific objectives were to examine if educational development and health development affects Nigeria's economic growth. The study used secondary data. The Statistical Package used in the analysis was E-views 7 to carry out the regression analysis using the Dynamic Ordinary Least Squares (DOLS) Method. Findings revealed that there is a positive impact between human capital development and economic growth. It 
was concluded that human capital development, educational development through government expenditure on education and health development through government expenditure on health, all have positive relationship with economic growth.

Jelilov, Aleshinloye and Önder [1] analyzed the impact of education on economic growth of Nigeria. The data used in this study were obtained from Central Bank of Nigeria Statistical Bulletin and World Bank data. The variables used in the study were Real Gross Domestic product (RGDP), capital expenditure on education, recurrent expenditure on education, primary school enrolment and secondary school enrolment from 1970 to 2015. The estimation of the model was via the OLS facilitated by the E-views application. The study therefore found that there is statistically significant relationship between GDP and all the variables used in the study with the exception of Primary School Enrolment (PRYE). The negative coefficient of the PRYE is also an indicator that there are problems at this level of education in Nigeria.

Obialor [14] examined the effect of government human capital investment on the economic growth of three SubSahara African (SSA) countries of Nigeria, South Africa and Ghana from 1980 to 2013 . The objective of the study was to analyze the growth effect of three government human capital investment variables of health, education and literacy rate on the economies of these countries. Secondary data were sourced from World Development Indicators (WDI) online Database and analyzed using Co-integration techniques and Vector Error Correction mechanism (VECM) at 1\% and 5\% significance levels. The results indicated that two out of the three human capital proxy variables: Health (GIH) and Education (GIE) showed significant positive effect on growth only in Nigeria, while literacy ratio (LR) is insignificantly positive in all countries. This study concluded that in spite of the above result, the SSA countries' economies still exhibit the potentials for enhanced economic growth in the long run judging from the VECM test results.

\section{Research Methods}

\subsection{Theoretical Framework}

The theoretical framework of this study is based on the Endogenous growth or the new growth theory developed by Solow [13]. The theory focused on tangible (physical) capital formation as the driver of economic growth. Oloyede [7] extended the framework of the theory by assuming that both physical capital and human capital are needed in the production process for economic growth. Interestingly, [19] in his study introduced the influence of technological progress on the production process. Solow's model also introduced Total Factor Productivity (TFP) growth, represented by parameter $A$, which is sometimes also referred to as the available technology stock.

The neo-classical growth model by Swan and Solow employed the Cobb-Douglas production function and assumed that gross domestic product $(\mathrm{Y})$ is a function of stock of capital, K (which may include human capital as well as physical capital), labour (L) and productivity of labour or knowledge (A), which grows over time (t) at an exogenous rate. Swan and Solow's production function exhibits constant returns to scale and is assumed to be capital- augmenting or Solow-neutral technology, as seen in the following CobbDouglas production function:

$$
\mathrm{Y}=\mathrm{f}(\mathrm{K}, \mathrm{AL})=\mathrm{AK}^{\alpha} \mathrm{L}^{(1-\alpha)}
$$

Where: $Y=$ Output in a given period,

$A=$ an index for the level of total factor productivity,

$K=$ the available level of physical capital,

$L=$ the available labor supply

$\alpha=$ a parameter that represents the capital elasticity with respect to output.

Equation [1] is the theoretical model that defines the effect of human capital quality on real sector output.

\subsection{Model Specification}

Adopting equation 1 framework, Lawanson [19] evaluated the impact of human capital expenditure on economic growth in Nigeria by stating their functional equation as follows:

$\mathrm{RGDP}=\alpha_{0}+\alpha_{1} \mathrm{PSE}+\alpha_{2} \mathrm{PEE}+\alpha_{3} \mathrm{PEH}+\alpha_{4} \mathrm{LE}+\alpha_{5} \mathrm{~K}+\mathrm{u}_{\mathrm{i}}(2)$

In equation 2 ,

RGDP $=$ Real Gross Domestic Product.

PSE $=$ Primary School Enrolment.

$\mathrm{PEE}=$ Public Expenditure on Education.

$\mathrm{PEH}=$ Public Expenditure on Health.

$\mathrm{LE}=$ Life Expectancy.

$\mathrm{K}=$ Stock of Physical Labour Force.

Adapting the model of Okojie [20] with modifications as follows: Real Gross Domestic Product (RGDP) was changed to agricultural sector output and Petroleum and Natural Gas sector. Primary School Enrolment (PSE), Public Expenditure on Education (PEE), Public Expenditure on Health (PEH), Life Expectancy (LE) and the Stock of Physical Labour Force $(\mathrm{K})$ were changed to Human Development Index (HDI), Educational Quality, Number of Infant Death, Labour Force Participation, Gross Capital Formation, Research and Development grant and credit disbursed to private sector respectively. Following this modification, the functional forms of the models to capture Agricultural and Petroleum and Natural Gas sectors are given thus:

$$
\begin{aligned}
\text { AGRO } & =\mathrm{f}(\text { HDI, PEDU, GHEE, LABF, RAD, CPS }) \\
\text { PNG } & =\mathrm{f}(\text { HDI, PEDU, GHEE, LABF, RAD, CPS })
\end{aligned}
$$

Adopting a log-linear specification, taking the natural logarithm of both sides of the equation and assuming linearity among the variables gives: 


$$
\operatorname{LnAGRO}=\alpha_{0}+\alpha_{1} \mathrm{HDI}_{\mathrm{t}}+\alpha_{2} \mathrm{PEDU}_{\mathrm{t}}+\alpha_{3} \mathrm{GHEE}_{\mathrm{t}}+\alpha_{4} \operatorname{Ln} \mathrm{LABF}_{\mathrm{t}}+\alpha_{5} \operatorname{LnRAD_{\mathrm {t}}}+\alpha_{6} \operatorname{LnCPS_{\mathrm {t}}}+\mathrm{u}_{\mathrm{t}}
$$

$$
\alpha_{1}>0, \alpha_{2}>0, \alpha_{3}>0, \alpha_{4}>0, \alpha_{5}>0, \alpha_{6}>0
$$

$$
\operatorname{LnPNG}=\eta_{0}+\eta_{1} \mathrm{HDI}_{\mathrm{t}}+\eta_{2} \mathrm{PEDU}_{\mathrm{t}}+\eta_{3} \mathrm{GHEE}_{\mathrm{t}}+\eta_{4} \operatorname{Ln} \mathrm{LABF}_{\mathrm{t}}+\eta_{5} \operatorname{LnRAD} \mathrm{R}_{\mathrm{t}}+\eta_{6} \operatorname{LnCPS_{\mathrm {t}}}+\mathrm{u}_{\mathrm{t}}
$$

$\eta_{1}>0, \eta_{2}>0, \eta_{3}>0, \eta_{4}>0, \eta_{5}>0, \eta_{6}>0$

Where:

AGRO = Agricultural Sector output ( billion) (proxy for agro industry performance)

$\mathrm{PNG}=$ Petroleum and Natural Gas Sector output ( billion) (proxy for petroleum and allied industry performance)

HDI = Human development index (A composite index measuring the quality of education, health and standard of living or well-being of nationals)

PEDU $=$ Percentage of education expenditure in total government recurrent expenditure (\%)

GHEE $=$ Percentage of total government expenditure on health infrastructure (\%)

$\mathrm{LABF}=$ Labour force participation (proxied by total number of labour force aged 15-65 years)

$\mathrm{RAD}=$ Research and development grant from local and foreign bodies ( $\$$ billion)

CPS $=$ Credit disbursed to private sector ( $\$$ billion)

$\alpha_{0} \& \eta_{0}=$ Constant of equations 3.5 and 3.6 respectively

$\alpha_{1}-\alpha_{6}$ and $\eta_{1}-\eta_{6}$, are all slopes of the estimate in equations

3.5 and 3.6 respectively

$\log =$ natural logarithm

$\mathrm{u}=$ Disturbance terms of the equations

$\mathrm{t}=$ time $($ yearly trend $)$

\subsection{Method of Data Analysis}

The econometric methods used in this study are time series analysis using the Augmented Dickey Fuller (ADF) unit-root test, Johansen Cointegration test, and the parsimonious Error Correction Model (ECM). The econometric package (Eviews 8 ) was used to analyse the data.

\subsection{Sources of Data}

The study employed annual time series data for the period 1990-2018. Secondary data utilized for the study were obtained from various issues of the Central Bank of Nigeria (CBN) Statistical Bulletin and the World Development Indicators (WDI) of the United Nations database and various issues of the CBN Statistical Bulletin.

\section{Data Presentation, Analysis and Discussion of Results}

\subsection{Presentation of Results}

\subsubsection{Unit Root Test}

From Table 1, the results on the ADF statistics indicated that HDI, PEDU and LABF were stationary at level i.e integrated at order zero $I(0)$ while the rest of the seriesAGRO, PNG, GHEE, RAD and CPS were stationary at first difference i.e or integrated at order one $I(1)$. Hence, the null hypothesis of no unit root exist was retained for HDI, PEDU and $\mathrm{LABF}$ but rejected for the rest of the series. This outcome provides sufficient reason for the researcher to proceed with further estimation as the trend or unit root that could result in a spurious estimate has been successfully eliminated by detrending the series. Before proceeding with estimating the equation, the optimum number of lags that is fit for the estimation of the equation was determined using

\begin{tabular}{|c|c|c|c|c|}
\hline Variable & $\begin{array}{l}\text { ADF calculated value in } \\
\text { Level }\end{array}$ & $\begin{array}{l}\text { ADF calculated value at } 1 \text { st } \\
\text { Difference }\end{array}$ & $\begin{array}{l}\text { McKinnon 5\% Critical } \\
\text { value }\end{array}$ & Order of Integration \\
\hline AGRO & -0.2926 & -4.7952 & -2.9810 & $I(1)$ \\
\hline PNG & -0.9059 & -4.8017 & -2.9810 & $I(1)$ \\
\hline HDI & -3.8631 & - & -2.9763 & $I(0)$ \\
\hline PEDU & -4.0080 & - & -2.9763 & $I(0)$ \\
\hline GHEE & -2.4405 & -5.6502 & -2.9810 & $I(1)$ \\
\hline $\mathrm{LABF}$ & -4.4705 & - & -3.0124 & $I(0)$ \\
\hline RAD & -2.1061 & -4.8715 & -2.9810 & $I(1)$ \\
\hline CPS & -1.9915 & -3.8098 & -2.9810 & $I(1)$ \\
\hline
\end{tabular}
two to three lag order selection criteria.

Table 1. Augmented Dickey-Fuller (ADF) test.

Source: Regression result

\subsubsection{Cointegration Test}

From the trace statistics in Table 2, the first and second null hypotheses were rejected at 5\% level of significance based on the decision rule that the probability value(s) is less than $5 \%(0.05)$. The trace statistics revealed that there are at least seven cointegrating equations or vectors among the variables respectively. Therefore, there exist a long run relationship among the series in model one 
Table 2. Cointegration Rank Test (Trace) on the Series in Model 1.

Series: AGRO HDI PEDU GHEE LABF RAD CPS

Lags interval (in first differences): 1 to 1

Unrestricted Cointegration Rank Test (Trace)

\begin{tabular}{|c|c|c|c|c|}
\hline Hypothesized & & Trace & 0.05 & \\
\hline No. of CE(s) & Eigenvalue & Statistic & Critical Value & Prob.** \\
\hline None * & 0.902542 & 192.1274 & 125.6154 & 0.0000 \\
\hline At most $1 *$ & 0.806185 & 131.5907 & 95.75366 & 0.0000 \\
\hline At most $2 *$ & 0.704553 & 88.92851 & 69.81889 & 0.0007 \\
\hline At most $3 *$ & 0.571334 & 57.22756 & 47.85613 & 0.0052 \\
\hline At most $4 *$ & 0.398044 & 35.20352 & 29.79707 & 0.0108 \\
\hline At most $5 *$ & 0.380537 & 22.00667 & 15.49471 & 0.0045 \\
\hline
\end{tabular}

Trace test indicates 7 cointegrating eqn(s) at the 0.05 level

* denotes rejection of the hypothesis at the 0.05 level

Table 3. Cointegration Rank Test (Trace) on the Series in Model 2.

Series: PNG HDI PEDU GHEE LABF RAD CPS

Lags interval (in first differences): 1 to 1

Unrestricted Cointegration Rank Test (Trace)

\begin{tabular}{|c|c|c|c|c|}
\hline Hypothesized & & Trace & 0.05 & \\
\hline No. of CE(s) & Eigenvalue & Statistic & Critical Value & Prob.** \\
\hline None * & 0.915121 & 216.9700 & 125.6154 & 0.0000 \\
\hline At most $1 *$ & 0.900423 & 152.8402 & 95.75366 & 0.0000 \\
\hline At most $2 *$ & 0.735574 & 92.86272 & 69.81889 & 0.0003 \\
\hline At most $3 *$ & 0.595809 & 58.27772 & 47.85613 & 0.0039 \\
\hline At most $4 *$ & 0.504998 & 34.72514 & 29.79707 & 0.0125 \\
\hline At most $5 *$ & 0.324941 & 16.44212 & 15.49471 & 0.0359 \\
\hline
\end{tabular}

Trace test indicates 7 cointegrating eqn(s) at the 0.05 level

* denotes rejection of the hypothesis at the 0.05 level

The result of the trace statistics in Table 3 indicated that the first and second null hypotheses should be rejected at 5 per cent level of significance. The trace statistics revealed that there are at least seven co-integrating equations. Therefore, there exist long run relationships among the series in third model.

The existence of a long run relationship among all the series in the models makes it possible for the researchers to determine how quickly the variables converge to equilibrium (i.e. the speed of adjustment back to long-run equilibrium after a perturbation, shock or a short-run disturbance). To determine this, the Parsimonious Error Correction Mechanism (ECM) was estimated.

\subsubsection{Error Correction Model Results}

The results of the parsimonious ECM are presented in this section

Table 4. Parsimonious Error Correction Mechanism (ECM) for Model 1.

Dependent Variable: $A G R O$

\begin{tabular}{|c|c|c|c|c|}
\hline Variables & Coefficient & Std. Error & t-Statistic & Prob. \\
\hline $\mathrm{C}$ & 0.122524 & 0.076478 & 1.602089 & 0.1276 \\
\hline $\mathrm{D}(\mathrm{HDI})$ & 0.371082 & 0.239523 & 1.549252 & 0.1397 \\
\hline D(PEDU) & 0.119154 & 0.031539 & 3.778006 & 0.0015 \\
\hline D(GHEE) & 0.017210 & 0.004956 & 3.472427 & 0.0029 \\
\hline $\mathrm{D}(\mathrm{LABF})$ & 8.914610 & 6.706828 & 1.329184 & 0.2014 \\
\hline $\mathrm{D}(\mathrm{RAD})$ & 0.075513 & 0.021705 & 3.479060 & 0.0029 \\
\hline $\mathrm{D}(\mathrm{CPS})$ & -0.163920 & 0.081350 & -2.015008 & 0.0600 \\
\hline ECM & -0.368406 & 0.118040 & -3.121027 & 0.0032 \\
\hline & & \multicolumn{3}{|c|}{ Diagnostic Statistics } \\
\hline R-squared & 0.620774 & \multicolumn{3}{|c|}{ Breusch-Pagan-Godfrey serial correlation LM test } \\
\hline Adjusted R-squared & 0.542315 & \multicolumn{2}{|c|}{ F-statistic $=0.7976$} & Prob. $F(2,15)=0.4686$ \\
\hline F-statistic & 3.478523 & \multicolumn{2}{|c|}{ Obs $*$ R-squared $=2.4991$} & Prob. Chi-Square $(2)=0.2866$ \\
\hline Prob(F-statistic) & 0.014656 & \multicolumn{2}{|c|}{ Heteroskedasticity Test: Harvey } & \\
\hline Durbin-Watson stat & 1.812586 & \multicolumn{2}{|c|}{ F-statistic $=1.3973$} & Prob. $F(8,17)=0.2665$ \\
\hline & & \multicolumn{2}{|c|}{ Scaled explained $\mathrm{SS}=5.5171$} & Prob. Chi-Square $(8)=0.7011$ \\
\hline
\end{tabular}




\begin{tabular}{|c|c|c|c|}
\hline Variables & Coefficient & Std. Error & Prob. \\
\hline \multicolumn{4}{|c|}{ Ramsey (RESET) test of model specification fitness } \\
\hline F-statistics $=2.4377$ & & Prob. $F(7,10)=0.4455$ & \\
\hline Likelihood ratio $=2.2295$ & & Prob. Likelihood ratio $(7)=0.3475$ & \\
\hline
\end{tabular}

Source: Regression result

The results in Table 4 indicates that the Error Correction Term (ECT) of -0.3684 is correctly signed and statistically significant at 0.05 level of significance $(p<0.05)$. This showed that in event of a disequilibrium resulting from a shock or disturbance, the system will restore itself back to equilibrium by an adjustment speed of approximately 36.8 percent. That is if there is disequilibrium in human capital development and related components; there will be a relatively slow speed of adjustment of about 36.8 per cent. Although, the one period lag of human capital development (HDI), one period lag of labour force participation (LABF) and credit to private sector (CPS) had direct impact on agrosector output in line with researcher's expectations, their effects were insignificant $(\mathrm{p}>0.05)$ in the short run. On the other hand, the one period lag coefficients of PEDU, GHEE, RAD and CPS all had direct significant effect on agro output in the period. This clearly indicates that the credit disbursed to the private sector for investment purposes as well as the expenditure on education, health and research and development (R\&D) are all lucrative human capital investments that impact on agricultural productivity in Nigeria.

The goodness of fit of the model (adjusted $\mathrm{R}^{2}$ ) indicated that approximately 54.2 to 65.1 per cent variations in the dependent variable (agro sector output) were explained by the independent variables. The F-statistic of 3.4785 showed that the independent variables are jointly significant in affecting variations in agro-sector output. This showed that the human capital development had contributory role to play in agricultural production output in Nigeria. Following the rule of thumb $(1.8 \geq \mathrm{DW} \leq 2.2)$, that is an approximately DW equal to 2, the Durbin Watson (D.W) statistic of 1.8125 showed that there is no presence of serial auto-correlation between or among the independent variables.

Two econometric diagnostic tests namely: Breusch-Pagan serial correlation LM test and the Harvey's test of Heteroskedasticity were carried for the study. The f-value of the Breusch-Pagan serial correlation LM test (0.7976) indicated that the null hypothesis of no serial correlation is accepted $(p>0.05)$. Similarly, the Harvey test for homoscedasticity has a null hypothesis which states that homoscedasticity exist. That is the variance of the error term is homoscedastic. Since the p-values of the statistics are greater than the appropriate threshold $(p>0.05)$, the null hypothesis of homoscedasticity is thereby retained.

In addition to this, the coefficients of Ramsey RESET (regression equation specification error test) were not statically significant $(\mathrm{p}>0.05)$. Hence, we cannot reject the null hypothesis of nonexistence of model error specification. Furthermore, the result from the Cumulative Sum (CUSUM) chart for model one on agricultural sector is given in Figure 1. The trend movement within the critical boundary lines shows that the estimated short-run model is structurally and dynamically stable for policy formulation.

Table 5. Parsimonious Error Correction Mechanism (ECM) for Model 2.

Dependent Variable: $P N G$

\begin{tabular}{|c|c|c|c|c|}
\hline Variables & Coefficient & Std. Error & t-Statistic & Prob. \\
\hline $\mathrm{C}$ & 0.086753 & 0.075079 & 1.155490 & 0.2649 \\
\hline D(HDI) & 0.367865 & 0.117844 & 3.121627 & 0.0032 \\
\hline D(PEDU) & 0.002448 & 0.025159 & 0.097308 & 0.9237 \\
\hline D(GHEE) & -0.008767 & 0.004650 & -1.885475 & 0.0777 \\
\hline $\mathrm{D}(\mathrm{LABF})$ & 6.913014 & 4.376223 & 1.579676 & 0.1337 \\
\hline $\mathrm{D}(\mathrm{LABF})$ & -14.86973 & 8.357238 & -1.779263 & 0.0942 \\
\hline $\mathrm{D}(\mathrm{RAD})$ & 0.132560 & 0.037770 & 3.509656 & 0.0029 \\
\hline $\mathrm{D}(\mathrm{CPS})$ & -0.105302 & 0.082960 & -1.269310 & 0.2225 \\
\hline ECM & -0.757232 & 0.253440 & -2.987810 & 0.0087 \\
\hline & & \multicolumn{3}{|c|}{ Diagnostic Statistics } \\
\hline R-squared & 0.618423 & \multicolumn{3}{|c|}{ Breusch-Pagan-Godfrey serial correlation LM test } \\
\hline Adjusted R-square & 0.503786 & \multicolumn{2}{|c|}{ F-statistic $=3.1608$} & Prob. $\mathrm{F}(2,15)=0.0737$ \\
\hline F-statistic & 2.881251 & \multicolumn{2}{|c|}{ Obs $*$ R-squared $=9.0881$} & Prob. Chi-Square $(2)=0.0775$ \\
\hline Prob(F-statistic) & 0.031223 & \multicolumn{2}{|c|}{ Heteroskedasticity Test: Harvey } & \\
\hline Durbin-Watson stat & & \multicolumn{2}{|c|}{ Scaled explained SS $=11.5529$} & Prob. Chi-Square $(8)=0.2397$ \\
\hline \multicolumn{5}{|c|}{ Ramsey (RESET) test of model specification fitness } \\
\hline \multirow{2}{*}{\multicolumn{2}{|c|}{$\begin{array}{l}\text { F-statistics }=0.6604 \\
\text { Likelihood ratio }=10.7780\end{array}$}} & \multicolumn{3}{|c|}{ Prof. $F(7.9)=0.7010$} \\
\hline & & \multicolumn{3}{|c|}{ PROF. Likelihood $\operatorname{ratio}(7)=0.1486$} \\
\hline
\end{tabular}

Source: Regression result 


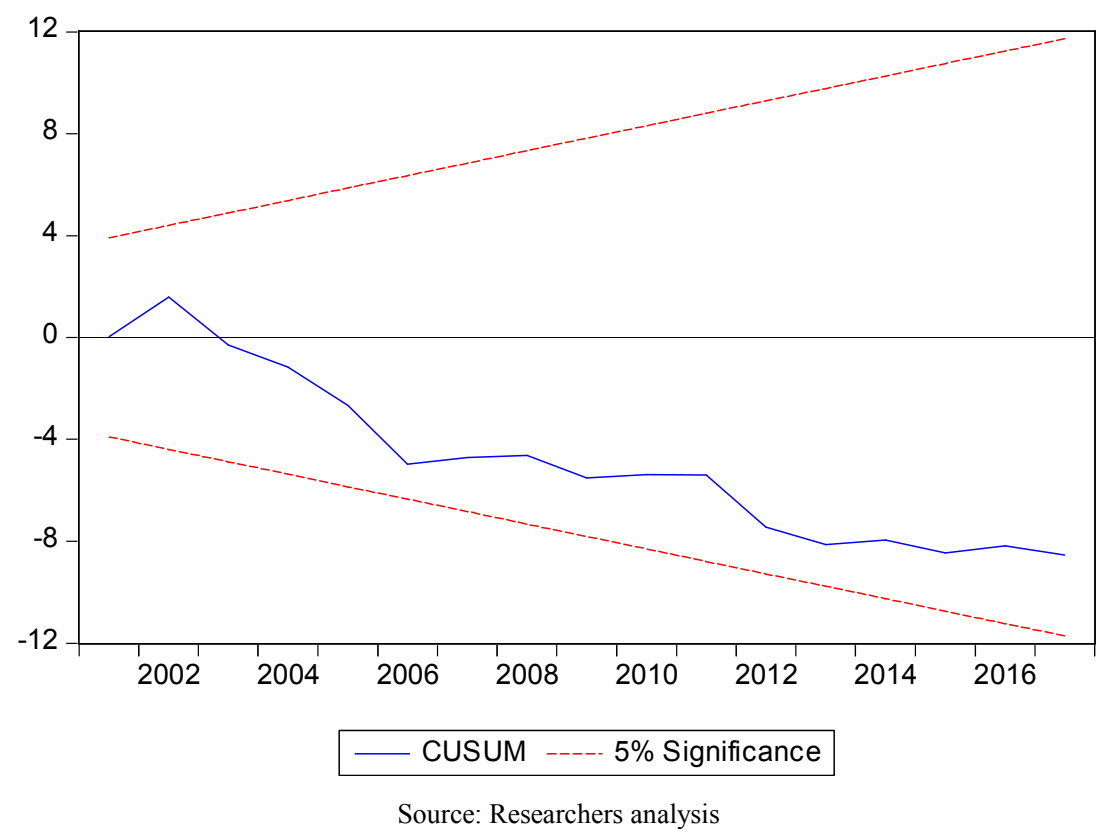

Figure 1. CUSUM chart for model stability within the year periods for Model 1 (Agricultural sector).

From Table 5, the Error Correction Term (ECT) of -0.7572 is correctly signed and statistically significant at 0.05 level of significance $(p<0.05)$. This speed is relatively higher than that of the agro and service sectors in that speed of adjustment in event of disequilibrium was about 75.7 percent. HDI, RAD and one period lag of RAD had direct and significant impact on the output from the petroleum and natural gas sector (PNG) of the country. This agrees with apriori expectations of the researchers. This clearly indicates that efforts at developing human capital through quality education, high health achievements, improved standard of living and investment in R\&D all contribute to productivity in the petroleum and natural gas sector.

The adjusted $\mathrm{R}^{2}$ showed that approximately 40.4 to 61.8 percent increment in the petroleum and natural gas sector (PNG) of Nigeria can be attributed to the quality of investment on the development of human capital. The F-ratio of 2.8812 showed that the explanatory variables jointly contribute to variations in the petroleum and natural gas sector (PNG) output. With a Durbin Watson (D.W) statistic of 1.8301, it is evident that there is no presence of serial auto-correlation between or among the independent variables following the rule of thumb $(1.8 \geq \mathrm{DW} \leq$ 2.2 ), that is an approximate DW statistic equal to 2 . The Breusch-Pagan serial correlation LM test and the Harvey's test of Heteroskedasticity were the diagnostic tests carried out for the study. The f-value of the Breusch-Pagan serial correlation LM test (3.1608) indicated that the null hypothesis of no serial correlation is accepted $(\mathrm{p}>0.05)$.

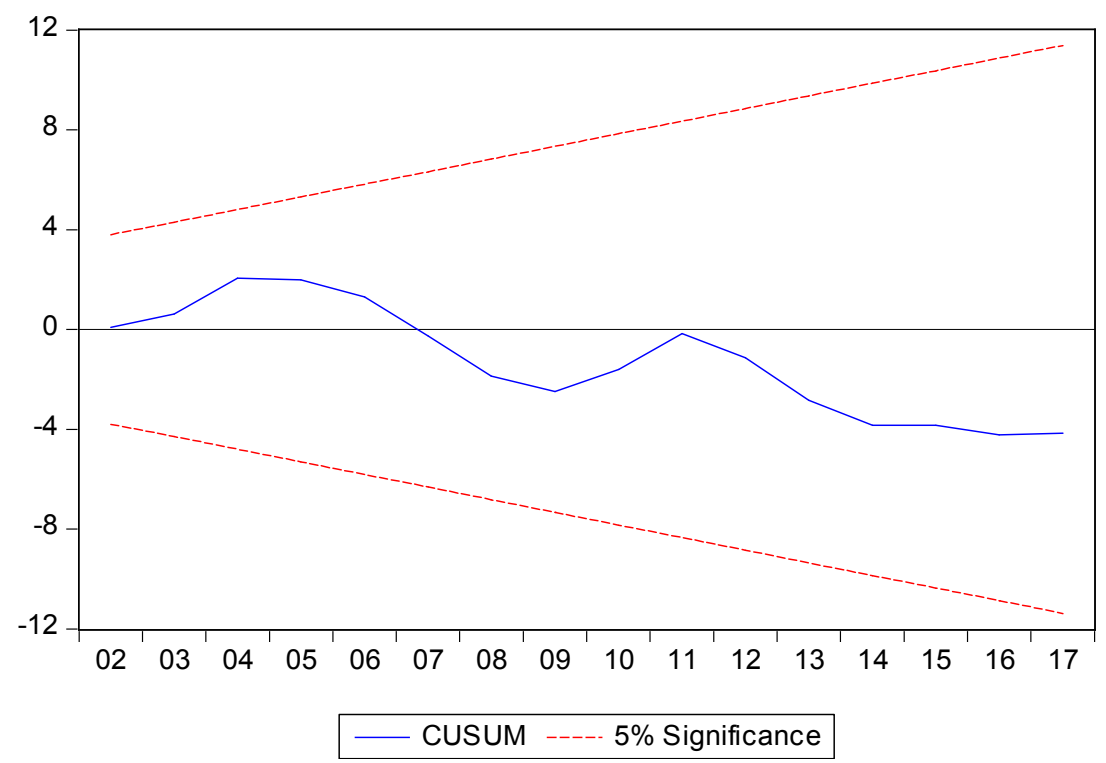

Source: Researchers analysis from Eviews 8

Figure 2. CUSUM chart for model stability within the year periods for Model 2 (Petrol and Natural gas sector). 
In addition to this test, the Harvey test for homoscedasticity which was carried out has a null hypothesis of homoscedasticity existence. Following the non-significance of the F-coefficient (0.9812) on the Harvey test $(p>0.05)$, the null hypothesis of homoscedasticity was thereby retained. In addition to this, the coefficients of Ramsey RESET (regression equation specification error test) were not statically significant $(\mathrm{p}>$ 0.05). Hence, we cannot reject the null hypothesis of nonexistence of model error specification. The result from the Cumulative Sum (CUSUM) chart for model three on the petroleum and natural gas sector is given in Figure 2. The trend movement within the critical boundary lines shows that the estimated short-run model is structurally and dynamically stable for policy formulation.

\subsection{Implications of the Results}

The result shows that the development of human capital is an investment of immense value in growth sustainability in the Petroleum and Natural Gas sector and Agricultural 'sectors. This result agrees with that of Kairo, Mang, Okeke and Aondo [21] who found that human capital development affects the entire sectors of the nation-public or private sectors. Also, both in the long and short run, government spending has remained positive but to a very large extent insignificant to human capital development in Nigeria. In a similar vein, the result corroborates that of Obialor [14] and Amassoma and Ikechukwu [22] who submitted differently that education and health among several other components of human capital development are critical public investments that cannot be neglected by the government in other to promote growth in the real sector and sustain the same over time.

The result concord to that of Jaiyeoba [5] who opined that human capital plays a positive role in per capita GDP growth only in the presence of better economic opportunities and high-quality legal institutions. The result agrees with that of Obialor [14] who attested that two human capital proxy variables: Health and Education showed significant positive effect on growth only in Nigeria. On the other hand, the result does not corroborates with that of Oloyede [7] who stated that there is negative long-run relationship among primary, tertiary school enrolment, public expenditure on health and real sector.

By implication, the result of this study has shown that productivity in the real sectors-Agricultural and Petroleum and Natural Gas sectors may be undermined where programmes that would develop human infrastructure such as education, health care and research and development are neither implemented nor adequately funded. This is because the quality of a nation's labour force is not only restricted to quality of knowledge or training but also in the extent to which they are introduced to innovative approaches and best practices on productive engagements in various segments of the real sector. This is implicative on the quality of financial, money and human resources invested in the area of research and development ( $\mathrm{R} \& \mathrm{D})$ to broaden the frontiers of knowledge and make new discoveries on faster, smarter and cost effective approaches of doing more with less resources.

\section{Summary, Conclusion and Recommendations}

\subsection{Conclusion}

The stock of a nation's wealth cannot be reduced to the quality of leadership infrastructure, its natural resource stock, or number of its labour force but more importantly; the quality of its human resource. The reason this assertion is largely deliberated upon by development economist, theorist and national leaders is because it is the people within a distinct and sovereign geographical boundary that constitute a nation. In an attempt to examine the nexus between human capital development and the real sector growth from a disaggregated approach; this study investigated the relationship between human capital development and sectoral growth in Nigeria. Annual time series data from 1990 to 2018 was collected from various issues of the Central Bank of Nigeria statistical bulletin and the World Development Indicator (WDI). Augmented Dickey Fuller (ADF), Johansen-Cointegration, and Error Correction Mechanism (ECM) were employed in the study. Long run relationship between human capital development and output growth in the two sectors examined.

Some of the findings from the study included;

i. There was the existence of a long run relationship among all the series in the two models used in the study.

ii. The Percentage of total government expenditure on health infrastructure (GHEE). Percentage of education expenditure in total government recurrent expenditure (PEDU), Credit disbursed to private sector (CPS) and Research and development grant from local and foreign bodies (RAD) and labour force participation (proxied by total number of labour force aged 15-65 years) were statistically significant.

iii. However, Human development index (A composite index measuring the quality of education, health and standard of living or well-being of nationals) was not statistically significant even though there was a direct relationship during the study period.

\subsection{Conclusion}

This study examined the impact of human capital development on some selected real sector between the period of 1999 and 2018. The study result indicated long run relationship between human capital development and output growth in two sectors investigated-Agriculture, and Petroleum and Natural Gas Sectors in Nigeria. The result uncovered that current public expenditure on education and health translated in increase in output for Petroleum and 
Natural Gas but not in the Agricultural sector. On the other hand, the one lagged period expenditure in research and development $(R \& D)$ had significant impact on output growth in both sectors.

\subsection{Policy Recommendations}

Based on the findings of this research, the following recommendations were made for policy implementation:

i. The federal government should endeavour to increase their educational expenditure at all levels to boost quality education infrastructure needed in all tiers of education that offer specialised courses such as School of Agriculture, School of Petroleum-Chemical Engineering among others. This is to enhance the quality of labour needed for the workplace in the real sector.

ii. In line with the recommendations of the United Nation in 2013 that about $26 \%$ of the nation's GDP and $15 \%$ of the government's total expenditure should be allotted to health services. The federal government should endeavour to comply with this standard to ensure quality health care service is relatively affordable for citizens.

iii. Financial and material resources should be invested by governmental agencies and ministries in order to promote Research and Development ( $\mathrm{R} \& \mathrm{D})$ to broaden the frontiers of knowledge and promote innovation in the real sector of the Nigerian economy.

\section{References}

[1] Jelilov, G. Aleshinloye, M. F. and Önder, S. (2016). Education as a key to economic growth and development in Nigeria. The International Journal of Social Sciences and Humanities Invention, 3 (2): 1862-1868.

[2] United Nations Development Programme (2016). Development for everyone. Washington DC: Communications Development Incorporated.

[3] Adelakun, O. J. (2011). Human Capital Development and Economic Growth in Nigeria European Journal of Business and Management 3 (9) 29-40.

[4] Ogunniyi, M. B. (2018). Human capital formation and economic growth in Nigeria: A time bound testing approach (1981-2014). African Educational Research Journal. 6 (2): 80-87.

[5] Jaiyeoba, S. V. (2015). Human capital investment and economic growth in Nigeria. An International Multidisciplinary Journal, Ethiopia, 9 (1), 30-46.

[6] Edun A. O., Akinde J. O., and Olaleye S. O. (2013) "Infrastructural Development and Its Effect on Economic Growth: The Nigerian Perspective," European Scientific Journal November 2013 edition vol. 9, No. 31.
[7] Oloyede, K. O. (2015). Impact of human capital development on economic growth in Nigeria, "International Journal of Humanities and Social Science 6 (2) 16-29.

[8] Todaro M. P. and Smith, S. C. (2003). Economic development (Eighth Edition), India: Pearson Education (Singapore) Pte Ltd.

[9] Imahe, O. J. (2018). Invest in human capital and prosper. An inaugural lecture delivered in the Chris Oyakhilome hall of Ambrose Alli University, Ekpoma, Edo State.

[10] Central Bank of Nigeria (2018). Statitical Bulletin.

[11] Obasanmi, J. O. (2018). Human Capital Development and Economic Growth in Nigeria. A disaggregated approach. African Journal of Business and Management, 6 (2) 11-24.

[12] World Bank (2016), World Development Indicators, 2016 Washington, D. C.: World Bank.

[13] Solow, R. M. (1956). A contribution to the theory of economic growth. The Quarterly Journal of Economics, 70 (1), 65-130.

[14] Obialor, M. C. (2017). Effect of government human capital investment on economic growth in sub-saharan Africa: Evidence from Nigeria, South Africa and Ghana. International Journal of Asian Social Science. 7 (4), 328-339.

[15] Olatubi, M. I., Oyediran, O. O., Adubi, I. O \& Oluwakemi, C. O. (2018). Health care expenditure in Nigeria and national productivity: a review. South Asian Journal of Social Studies and Economics 1 (1): 1-7.

[16] Organisation for Economic Co-operation and Development (OECD) 2016: Educationa at a glance. Extracted from https://www.oecd.org/education/skills-school/EAG2016Annex3.pdf on 12/07 / 2019.

[17] Temple J. (1999): The new growth evidence. Journal of Economic Literature 112-156.

[18] Schultz T. P. (1992): 'The role of education and human capital on economic development'. An empirical assessment center discussion paper, economic growth center, Yale University.

[19] Lawanson, O. I. (2009). Human capital investment and economic development in Nigeria: The role of education and health. Oxford Business \& Economics Conference Programme.

[20] Okojie, C. E. E. (1995): Human capital formation for productivity growth in Nigeria: The Nigerian economic and financial review. 44-52.

[21] Kairo, C. I., Mang N. J., Okeke, A. \& Aondo, D. C. (2017). Government expenditure and human capital development in Nigeria: an auto-regressive distributed lagged model approach (ARDL). International Journal of Advanced Studies in Economics and Public Sector Management, 5 (1), 143-158.

[22] Amassoma, D. \& Ikechukwu, E. (2016). A reappraisal of the nexus between investment in human capital development and economic growth in Nigeria. Journal of Entrepreneurship, Business and Economics, 4 (2), 59-93. 